\title{
Evaluation of best management practices to reduce nutrient contaminant losses in runoff from broiler litter-amended soils. II. Grass cover $^{1,2}$
}

\author{
Gustavo A. Martínez-Rodríguez ${ }^{3 *}$, Raúl Macchiavellit ${ }^{4}$ and \\ Miguel A. Vazquez ${ }^{5}$
}

J. Agric. Univ. P.R. 94(1-2):61-77 (2010)

\begin{abstract}
The effect of Bermuda grass [Cynodon dactylon (L.)] cover on sediment and nutrient runoff losses from untreated as well as from broiler litter (with alum)-amended soil was evaluated. Runoff generated from a completely bare soil had significantly higher runoff volumes, as well as more suspended solids (SS), total phosphorous (TP), and total Kjeldahl nitrogen (TKN) concentrations than soils with $\geq 80 \%$ grass coverage. In addition, bare soils exhibited less time to runoff (time span between rainfall initiation and the start of runoff) than the grass-covered treatments. Average TP and TKN concentrations in runoff from experimental trays having $\geq 80 \%$ grass coverage were reduced by $93 \%$ and $89.5 \%$, respectively, as compared to concentrations in bare soil runoff. Similarly, suspended solid concentration showed a reduction of $99 \%$ over that of the bare soils. Dissolved P (DP) concentration losses were well below the $1 \mathrm{mg} / \mathrm{L}$ limit suggested to control $P$ contamination from agricultural lands, even for the broiler litter-amended soils. In general, both TP and TKN concentrations followed the trend established by suspended sediment losses. In contrast, nitrate exhibited a negative correlation with SS concentrations. Applications of broiler litter caused significant increases in the dissolved constituents (i.e., DP and $\mathrm{NO}_{3}-\mathrm{N}$ ) concentrations in runoff but not in those constituents (i.e., TP and TKN) for which sediment losses represent a significant transport mechanism. A significant decrease in SS concentrations was observed with time at both cover categories, with losses being much higher from the bare soils than from the grass-covered soils. Broiler litter applications caused a significant reduction in SS concentration losses at each grass cover category (although much higher losses were observed from bare soils). The combination of alum application and a good
\end{abstract}

${ }^{1}$ Manuscript submitted to the Editorial Board on 28 October 2009.

${ }^{2}$ We appreciate the collaboration of José L. Guzmán, Onilda Santana, Vidal Santiago and Francisco Castro on this project.

${ }^{3}$ Professor, Crops and Agroenvironmental Sciences Department, College of Agricultural Sciences, University of Puerto Rico- Mayagüez Campus. *For correspondence: Email: tavomarti@hotmail.com

${ }^{4}$ Professor, Crops and Agroenvironmental Sciences Department, College of Agricultural Sciences, University of Puerto Rico.

${ }^{5}$ Research Associate, Crops and Agroenvironmental Science Department, Agricultural Experiment Station at Río Piedras, Puerto Rico. 
grass cover $(280 \%)$ reduced estimates of sediment, TP, and TKN runoff export loads by more than $95 \%$ relative to that of the runoff from bare soil.

Key words: simulated rainfall, runoff, best management practices, pasture cover, alum, water quality, nutrients, tropical soils

\section{RESUMEN}

Evaluación de mejores prácticas de manejo para reducir las pérdidas de nutrientes contaminantes en escorrentía desde suelos enmendados con camada de pollos parrilleros. II. Cobertura de hierbas

Se evaluó el impacto de la extensión de la cobertura del pasto Bermuda [ $C y$ nodon dactylon (L.)] en la pérdida de sedimentos y nutrientes en escorrentía en suelos enmendados con residuos de camada de pollos parrilleros (con alum). La escorrentía generada de los suelos completamente descubiertos reflejó valores significativamente mayores en los volúmenes de escorrentía y en las concentraciones de sólidos suspendidos, fósforo total (TP) y nitrógeno total Kjeldahl (TKN), que en suelos con $\geq 80 \%$ de cobertura de pasto. Además, el suelo descubierto exhibió un tiempo de inicio de escorrentía menor (lapso de tiempo entre inicio de la lluvia y el comienzo de la escorrentía) que los suelos con pasto. Las concentraciones promedio de P total y TKN en la escorrentía de bandejas experimentales con $\geq 80 \%$ de cobertura de hierba exhibieron una reducción de $93 \%$ y $89.5 \%$, respectivamente, comparado con aquellas en la escorrentía de las bandejas con suelo al descubierto. Por otra parte, la concentración de sólidos suspendidos mostró una reducción de $99 \%$ sobre la del suelo al descubierto. Las pérdidas en fósforo disuelto estuvieron bien por debajo del límite de $1 \mathrm{mg} / \mathrm{L}$ sugerido como el nivel para el control de contaminación de fósforo de tierras agrícolas, incluyendo suelos enmendados con residuos de camada de pollos parrilleros. En el caso de estos residuos, el resultado es un reflejo de la efectividad del alum en la reducción de la pérdida de fósforo disuelto en la escorrentía. En general, tanto las concentraciones de $\mathrm{P}$ total como TKN siguieron las tendencias establecidas por las pérdidas de sedimentos. Una disminución significativa en la concentración de sedimentos suspendidos fue observada con el tiempo en ambos tipos de coberturas del suelo, con pérdidas significativamente más altas en suelos al descubierto que en suelos con cobertura vegetal. En contraste, el nitrato exhibió una correlación negativa con las concentraciones de sólidos suspendidos. Aplicaciones de residuos de camada de pollos parrilleros causaron un aumento significativo en las concentraciones de los constituyentes disueltos (i.e., $\mathrm{P}$ disuelto y $\mathrm{NO}_{3}-\mathrm{N}$ ) en la escorrentía, pero no así de otros constituyentes (i.e., $P$ total y TKN) para los cuales las pérdidas de sedimentos representan un mecanismo significativo de transporte. La aplicación de residuos de camada de pollos parrilleros redujo significativamente la pérdida en la concentración de sólidos suspendidos para cada categoría de cubierta vegetal, aunque una pérdida mucho mayor fue observada para el suelos al descubierto. La combinación de aplicación de alum y una buena cobertura de hierba $(2 \mathbf{8 0} \%)$ reduce los estimados de carga de exporte de sedimentos suspendidos, P total y TKN en la escorrentía por más de un $95 \%$ comparado con los de los suelos al descubierto.

Palabras clave: simulación de lluvia, escorrentía, mejores prácticas de manejo, cobertura de hierbas, alum, calidad de agua, nutrientes, suelos tropicales

\section{INTRODUCTION}

During the last two decades much effort and many resources have been committed to reducing the contribution of pollutants from non- 
point sources to water resources. Particular attention has been devoted to the reduction of nutrients, sediment, and microbial pathogen loads, which are the main contaminants of rivers/streams and lakes/reservoirs in the U.S. (USEPA, 1999). Agricultural activities are recognized as one of the largest potential contributors of those contaminants, and as a result these activities have been a main target of the mitigation effort. A series of best management practices are now mandatory as part of the conservation management plan of any farm in the U.S. benefiting in any form from any U.S. government program (USDA, 2001). Among the most recommended best management practices is the use of vegetative barriers (USDA-NRCS code 601), and the use of cover crops (USDA-NRCS code 340).

Vegetative barriers are defined as narrow, permanent strips of dense, perennial vegetation established in parallel rows perpendicular to dominant slope of the field. Vegetative barriers reduce sediment losses from the overland flow by decreasing its velocity and allowing particles to settle. In addition, increased water infiltration into the soil profile aids in sediment interception by decreasing the amount of runoff (Polyakov et al., 2005). Sediment-trapping efficiencies anywhere from $60 \%$ to $98 \%$ have been reported (Magette et al., 1998; Lim et al., 1998; Sheridan et al., 1999).

Cover crops are similar to vegetative barriers but span over a much more extensive area. Research in Puerto Rico has focused on the use of cover crops as an erosion control practice. Smith and Abruña (1955) estimated that sediment losses from a steep slope soil under fallow averaged $284 \mathrm{t} / \mathrm{ha} / \mathrm{yr}$, whereas the same soil under different cover crops exhibited a $98 \%$ reduction in sediment loss (i.e., $4.93 \mathrm{t} / \mathrm{ha} / \mathrm{yr}$ ). Total runoff volume from the cover crop plots also showed a $61 \%$ reduction relative to that from the bare soil (Smith and Abruña, 1955).

The effects of a constant vegetated stand on sediment transport also affect off-field nutrient transport. Phosphorus removal rates as high as 93\% have been reported from a vegetated filter zone, although in general removal efficiencies range from $60 \%$ to $90 \%$ (Lim et al., 1998; Line et al., 2000). The fraction of phosphorus that is transported in runoff is also affected by a vegetation barrier. The largest portion (75 to $95 \%$ ) of $\mathrm{P}$ losses coming from cropland is particulate $\mathrm{P}$; however, as the percentage pasture coverage in a field increases, a change in favor of the dissolved $\mathrm{P}$ fraction is generally observed.

Broiler farms in Puerto Rico generally maintain a pasture cover stand of $\geq 80 \%$ soil coverage (Martínez et al., 2002). The fact that most of this area is generally used for litter application invalidates it from being considered a vegetated barrier zone in terms of nutrient removal. However, its effects on sediment export losses, and thus indirectly on 
the form of nutrient (i.e., dissolved vs. particulate phosphorus) exiting the farms, deserve consideration. In an accompanying paper (Martínez et al., 2010) our research group evaluated the effect of alum on P transport losses from plots amended with broiler litter. This study considers the effect of grass coverage on nutrient and sediment transport from experimental trays without broiler litter vs. those amended with broiler litter treated with alum.

The objectives of this study were to evaluate the effect of grass coverage on sediment and nutrient runoff losses from untreated and broiler litter-amended soils, and to evaluate the effect of rainfall frequency on the composition of runoff from bare and from grass-covered soils.

\section{MATERIALS AND METHODS}

This study followed an experimental strategy similar to that detailed in a companion study (Martínez et al., 2010). Three rainfall simulation events followed the guidelines of the National Research Project for Simulated Rainfall (indoor runoff box protocol) (USDA-NRCS, 2001) using the same rainfall simulation assembly described by Martínez et al. (2010). Simulated rainfall events were performed at 0 day (initial event performed six months after broiler litter application), seven and 21 days after initial event. Unlike the companion study, in which a "wet" event was performed 24 hours after the first event, this study did not include a "wet" event.

Twenty-four runoff boxes were used. The boxes were filled with surface soil ( 0 to $7.5 \mathrm{~cm}$ ) of the Corozal (Typic Hapludults) series. After collection from the field, the soil was air dried, thoroughly mixed and passed through a 2-mm sieve. The boxes were packed with enough soil to achieve a final bulk density of approximately $1.1 \mathrm{~g} / \mathrm{cm}^{3}$. The boxes were left untreated for one month (with periodical wetting-drying cycles) to allow for soil stabilization.

A broiler litter (BL) application rate of $20 \mathrm{t} / \mathrm{ha}$ containing alum $\left[\mathrm{Al}_{2}\left(\mathrm{SO}_{4}\right)_{3} \cdot 14 \mathrm{H}_{2} \mathrm{O}\right]$ at a $20 \% \mathrm{w} / \mathrm{w}$ rate was evaluated. An untreated control was also included. The BL was broadcasted over the soil surface five months prior to grass seeding. This setup presents a completely different scenario from the one used in the companion study (Martínez et al., 2010). In the latter, the BL was applied on top of an already established grass, whereas in this case the broiler litter was applied well before grass seeding. The above mentioned study simulates the common disposal practice of broiler litter within the farm owner's fields, whereas this study simulates a recently popular trend of broiler litter applications on new fields located on recipient farms. 
Two coverage categories were evaluated: control (bare soil) and $\geq$ $80 \%$ coverage of Bermuda grass [Cynodon dactylon (L.)]. Once the Bermuda grass was well established (approximately one month after seeding), the simulation runs were initiated. On each simulation run, the boxes were placed on a metal frame inclined at a $20 \%$ slope to simulate field conditions. Rainfall was applied until 30 minutes of runoff was produced from each box. The bulk runoff volume generated was collected in a 19-L plastic container. Separate runoff aliquots $(100 \mathrm{ml})$ were collected at three and 30 minutes after runoff initiation. Samples were analyzed for total and dissolved P (EPA method 365.4); TKN (EPA method 351.2); $\mathrm{NO}_{3}-\mathrm{N}$ (EPA method 353.2); and for suspended sediments. Sediment content was determined by weight by filtering a known sample volume $(100 \mathrm{ml})$ through a previously oven-dried $\left(105^{\circ} \mathrm{C}\right)$ and weighed glass fiber filter. The filter containing the sediment sample was submitted to another drying period $\left(18 \mathrm{~h}\right.$ at $\left.105^{\circ} \mathrm{C}\right)$ prior to the final weight determination. Samples for $\mathrm{NO}_{3}-\mathrm{N}$ and for dissolved $\mathrm{P}$ were filtered through a $0.45-\mu m$ Gelman acrodisc filter before analysis. Time to runoff initiation, and total runoff volume produced were measured in each case. Upon completion of all simulation runs, soil $(0$ to $7.5 \mathrm{~cm})$ and tissue samples were obtained from each tray. Soil samples (air-dried and sieved) were analyzed for available P (Olsen and Bray I).

Statistical analyses were conducted by using the $\mathrm{SAS} \otimes$ software program (SAS System v. 9.1) using a model with four factors: grass cover, litter treatment, simulation date, and time after runoff initiation (TAR), and their interactions. In addition, we included random effects to model the split-split plot design, with treatment (grass cover of BL rate) as main plot factor, and date and TAR as the subplot and sub-subplot factors, respectively. In all cases except runoff volume, a transformation $[\operatorname{Ln}(\mathrm{y})]$ of the experimental data was used to achieve normality.

\section{RESULTS AND DISCUSSION}

Broiler litter (BL) was applied at a rate of $20 \mathrm{t} / \mathrm{ha}$ in a treatment containing a mixture of alum at a $20 \%(\mathrm{w} / \mathrm{w})$ dosage. This combined (BL + alum) treatment significantly increased the available soil test P levels (Olsen) with respect to levels in the untreated control $(12.3 \mathrm{mg} / \mathrm{kg})$ to an average value just above the agronomic criteria (i.e., $37.78 \mathrm{mg}$ / $\mathrm{kg})$. However, this value is lower than the average value obtained with a similar application rate in the companion study (i.e., $93.71 \mathrm{mg} / \mathrm{kg}$ ) and substantially lower than the average soil $\mathrm{P}$ value obtained with a similar broiler litter rate (i.e., $20 \mathrm{t} / \mathrm{ha}$ ) without alum $(276.75 \mathrm{mg} / \mathrm{kg})$ (Martínez et al., 2010). The difference between the values obtained for the $20 \mathrm{t} / \mathrm{ha}-20 \%$ alum treatments can be explained by the difference in 
the experimental protocol (see materials and methods section) between the two studies. But more importantly, the results of both studies evidenced the potentially significant role of alum in reducing the available $P$ fraction from broiler litter-amended fields.

A highly positive correlation was found between the Olsen and Bray-I soil test $\mathrm{P}$ values measured in the experimental trays (Figure 1). The slope value of the resulting linear expression was similar to that reported by Sotomayor et al. (2004) for a series of soils amended with different rates of inorganic or organic P. Both grass coverage (GC) and BL applications had a significant impact on runoff composition. Since there was no significant interaction (GC * BL) between the main treatments (except for TKN), their effects will be discussed separately.

\section{Effect of grass cover}

Runoff generated from a completely bare soil had significantly higher total P, TKN and suspended solid concentrations, as well as lower DP/TP ratios and higher runoff volumes than soils with $\geq 80 \%$ grass coverage (Table 1). Barren soils also exhibited lower time to runoff initiation values (time span between rainfall initiation and the start of runoff) than soils with extensive grass coverage.

Vegetative covers reduce sediment and sediment-attached contaminants from runoff by reducing its lateral flow speed and thus allowing

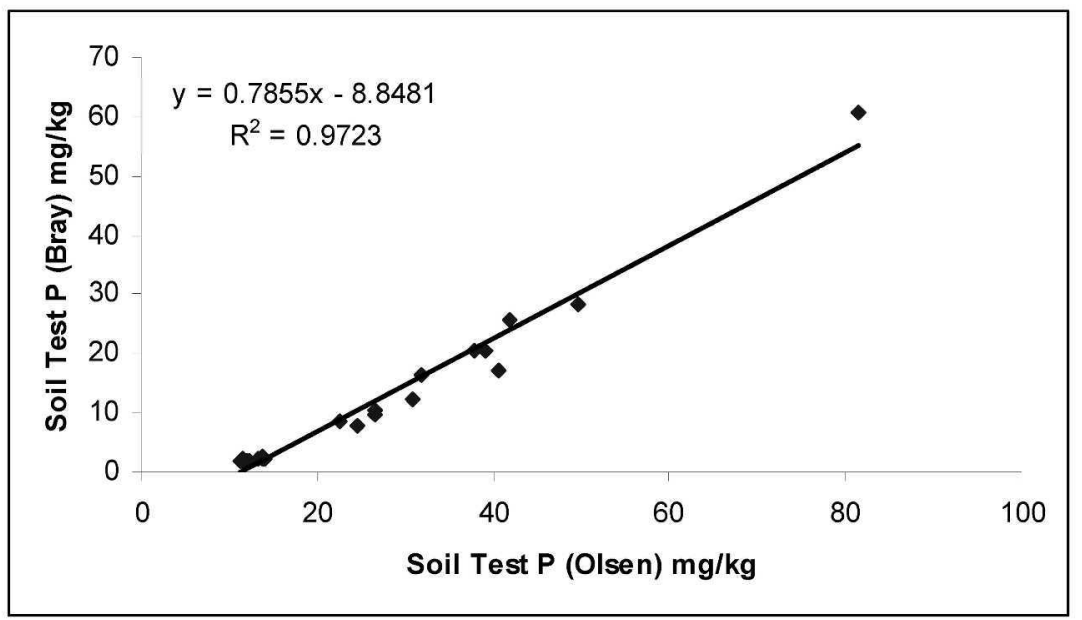

FIGURE 1. Relationship between Olsen and Bray I soil test $\mathrm{P}$ level in the experimental units used in this study. 
TABLE 1. Effect of grass coverage percentage on runoff composition.

\begin{tabular}{lccccc}
\hline & \multicolumn{2}{c}{ Grass Cover $(\mathrm{GC})(\%)$} & & \multicolumn{2}{c}{ Broiler Litter rate (t/ha) } \\
\cline { 2 - 3 } \cline { 6 - 7 } Parameter & 0 & 280 & & 0 & 20 \\
\hline $\mathrm{TP}(\mathrm{mg} / \mathrm{L})$ & $7.87 \mathrm{a}^{1}$ & $0.51 \mathrm{~b}$ & & $1.78 \mathrm{a}$ & $2.26 \mathrm{a}$ \\
$\mathrm{DP}(\mathrm{mg} / \mathrm{L})$ & $0.032 \mathrm{a}$ & $0.034 \mathrm{a}$ & & $0.007 \mathrm{~b}$ & $0.15 \mathrm{a}$ \\
$\mathrm{DP} / \mathrm{TP} \%$ & $0.41 \mathrm{~b}$ & $6.60 \mathrm{a}$ & & $0.41 \mathrm{~b}$ & $6.62 \mathrm{a}$ \\
$\mathrm{NO} \mathrm{O}_{3}-\mathrm{N}(\mathrm{mg} / \mathrm{L})$ & $1.74 \mathrm{a}$ & $3.16 \mathrm{a}$ & & $1.30 \mathrm{~b}$ & $4.22 \mathrm{a}$ \\
$\mathrm{TKN}(\mathrm{mg} / \mathrm{L})$ & $25.84 \mathrm{a}$ & $2.71 \mathrm{~b}$ & & $10.44 \mathrm{a}$ & $6.70 \mathrm{~b}$ \\
$\mathrm{SS}(\mathrm{g} / 100 \mathrm{ml})$ & $0.90 \mathrm{a}$ & $0.01 \mathrm{~b}$ & & $0.18 \mathrm{a}$ & $0.06 \mathrm{~b}$ \\
Time to runoff $(\mathrm{min})$ & $3.21 \mathrm{~b}$ & $8.15 \mathrm{a}$ & & $5.15 \mathrm{a}$ & $5.06 \mathrm{a}$ \\
Runoff volume $(\mathrm{ml})$ & $4,274 \mathrm{a}$ & $2,565 \mathrm{~b}$ & & $3,464 \mathrm{a}$ & $3,376 \mathrm{a}$ \\
\hline
\end{tabular}

${ }^{1}$ Within a row, means followed by the same letter are not different at the $\alpha=0.05$ level of probability according to a LSD test.

particles to settle (Polyakov et al., 2005). Increased water infiltration into the soil profile also promotes reduced runoff volumes. The magnitude of the impact of these mechanisms can certainly be appreciated by the results of this study. Average TP and TKN concentrations in runoff from a soil having $\geq 80 \%$ pasture coverage exhibited a reduction of $93.5 \%$ and $89.5 \%$, respectively, relative to runoff from the bare soils (Table 1). In addition, the suspended solid concentrations showed a reduction of $99 \%$ over that of the bare soils, similar to what was reported by Smith and Abruña in 1955. The concentrations of these three constituents (i.e., TP, TKN, and SS) in the runoff generated from the bare soils are high enough to cause impairment. For instance, the average suspended solid concentration $(9,000 \mathrm{mg} / \mathrm{L})$ is much higher than the current water quality standard for rivers and streams in Puerto Rico (i.e., $500 \mathrm{mg} / \mathrm{L}$ ) (Puerto Rico Environmental Quality Board, 2008). In this sense, maintaining a good grass stand constitutes a highly efficient management practice to reduce the sedimentation of our rivers and reservoirs. Most broiler farms in Puerto Rico are characterized by fields with $>80 \%$ grass coverage. Thus, in the case of sediments broiler farms can be considered a sink rather than a source of contamination.

Grass cover had a different impact on concentration losses of moieties (i.e., $\mathrm{DP}$ and $\mathrm{NO}_{3}-\mathrm{N}$ ) whose main transport mechanism is based on the aqueous-dissolved fraction (as opposed to particulate-attached) in runoff. Grass cover percentage did not have a significant impact on DP concentration losses (Table 1). In both treatments, concentration losses were well below the $1 \mathrm{mg} / \mathrm{L}$ limit suggested to control P contamination from agricultural lands. On the other hand, nitrate losses exhibited a trend towards higher losses from the Bermuda grass treatments than from bare soils. Results were significant at $90 \%$ level (Table 1 ). 
In general, both TP and TKN concentration followed the trend established by suspended sediment losses (Figures 2 and 3). In fact, a high positive correlation was observed between these two parameters (i.e., TKN and TP) in all cases except for the untreated (no litter) bare soils (Figures 4 and 5). A significant decrease in SS concentrations was observed with time in both cover categories, although as previously stated, losses remained much higher on the bare soils than on the grass covered soils at all times (Table 2). A similar reduction in concentration losses with time was observed for TKN and TP concentrations, although in the case of TP differences with time were not significant for the bare soil (Table 2). Contrary to TP and TKN, nitrate concentration losses from the bare soil were negatively correlated to SS concentrations in runoff (Figure 6). A closer look at the data reveals that this finding was probably due to the effect of BL applications on sediment losses from the bare soil. That is, although BL increased nitrate concentration losses it had an inverse effect on suspended sediment losses from the bare soil, creating in turn an opposite relationship between those constituents. Nitrate losses from the grass-covered soils exhib-

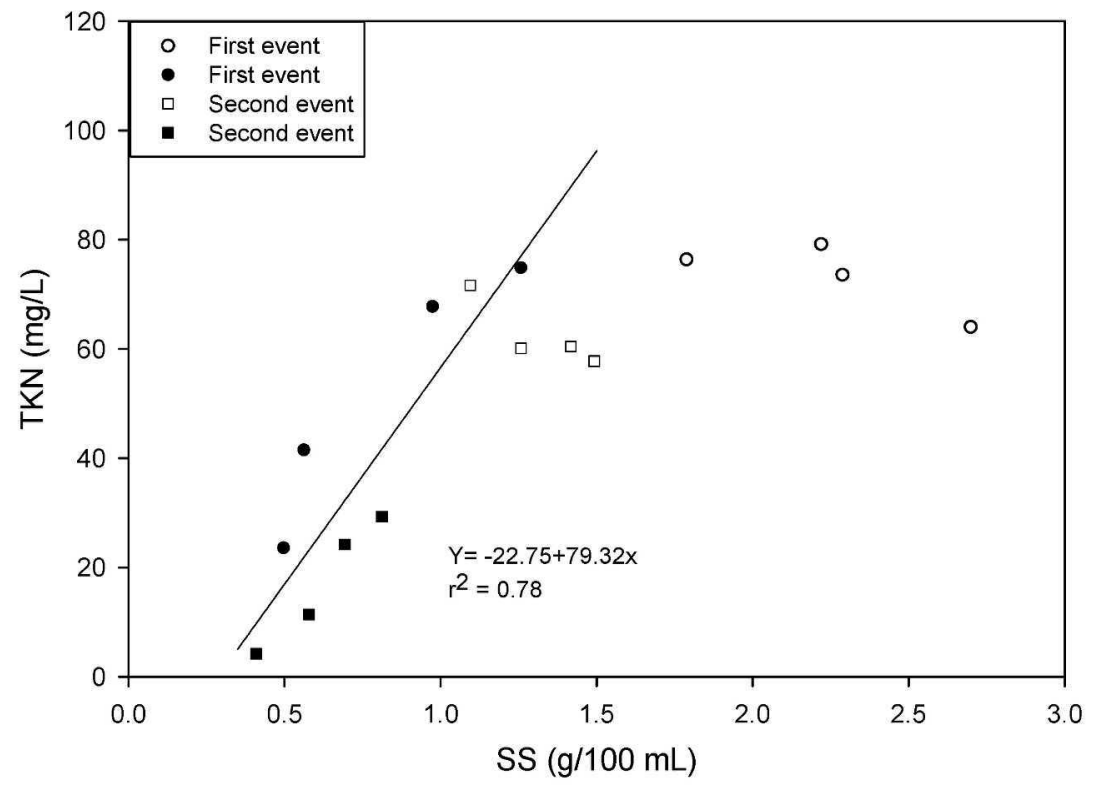

FIGURE 2. Relationship between suspended sediment concentrations and TKN concentration values in runoff for the bare soils. Open symbols represent average values from unamended experimental units and filled symbols average values from broiler litter-amended units. Regression line corresponds to BL data only. 

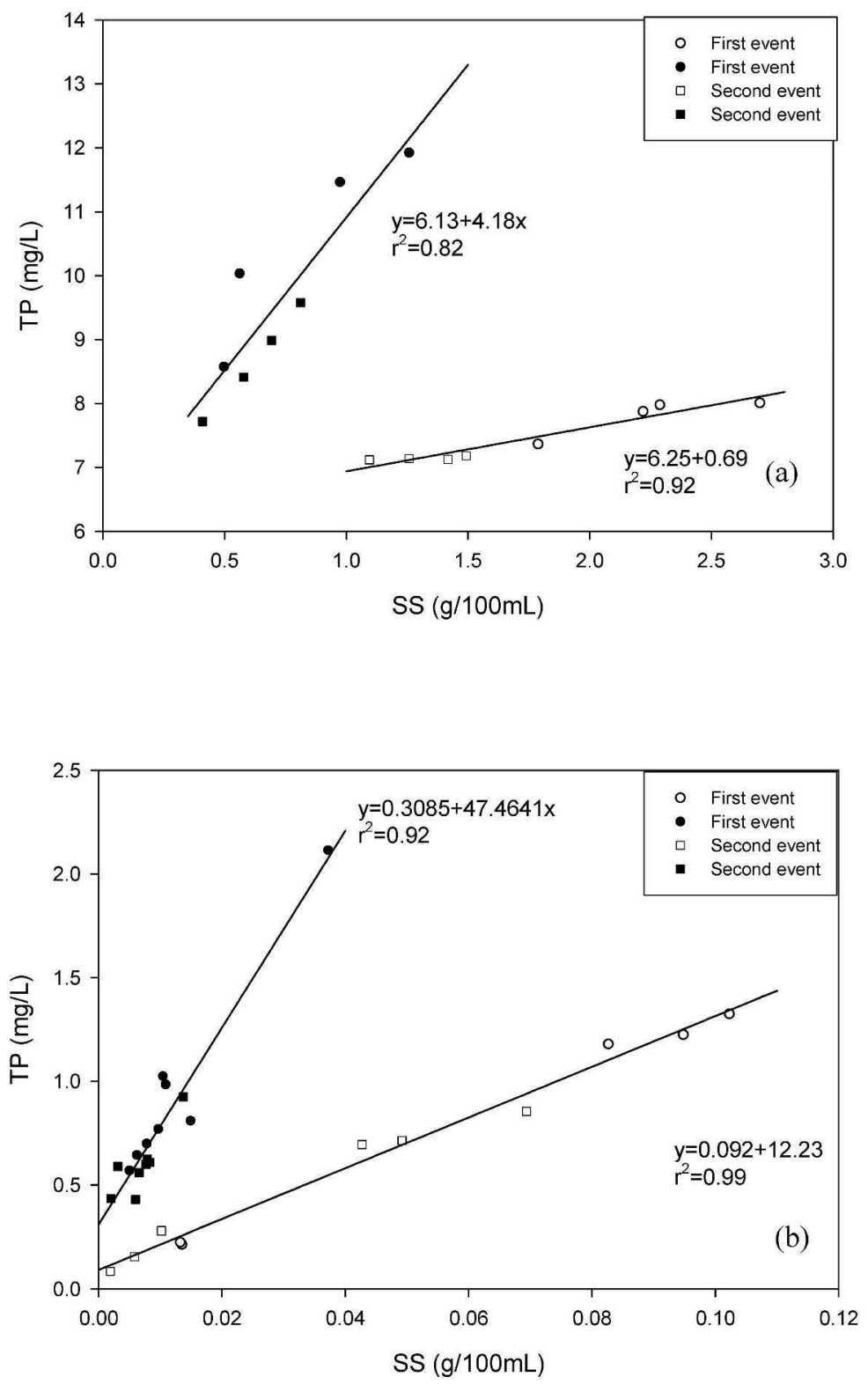

FIGURE 3. Relationship between suspended sediment concentrations and TP concentration values in runoff. a) grass covered $(\geq 80 \%)$ soils; b) bare soils. Open symbols represent unamended experimental units and filled symbols represent broiler litteramended units. 


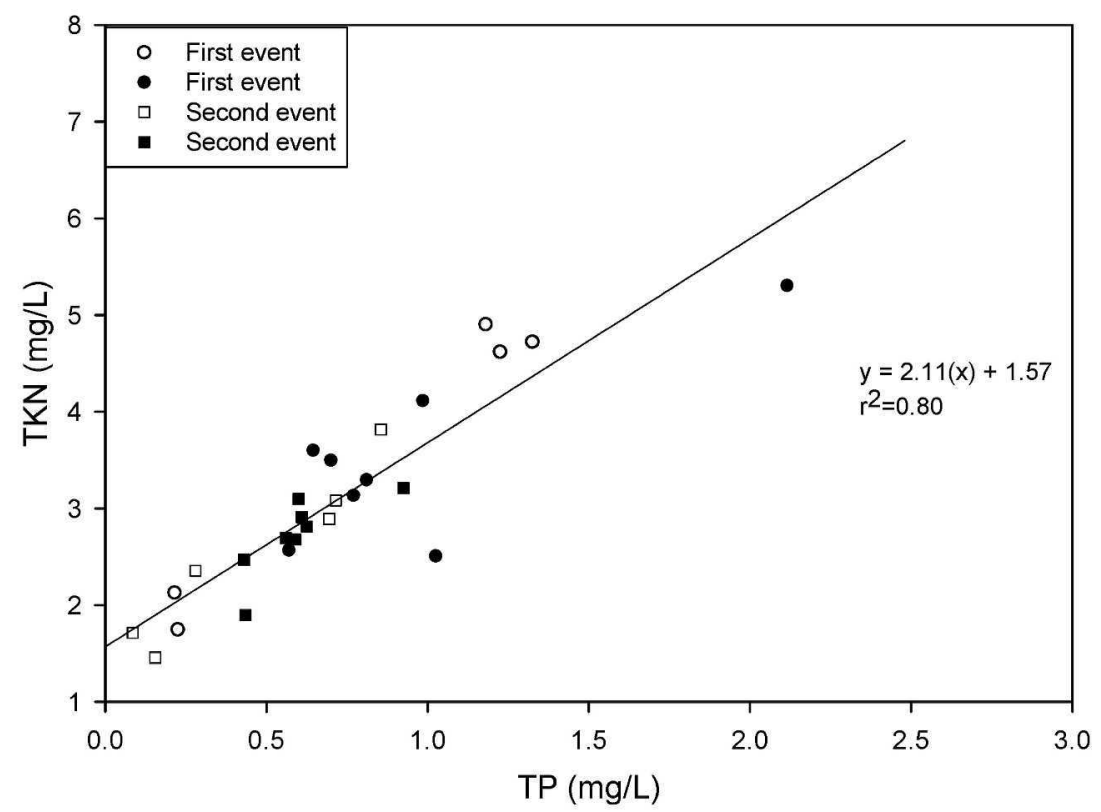

FIGURE 4. Relationship between TP and TKN concentrations in runoff for the grass covered ( $\geq 80 \%)$ soils. Open symbols represent unamended experimental units and filled symbols represent broiler litter-amended units.

ited a concentration loss pattern similar to that observed in the companion study, that is, an initial high concentration flush during the first event, followed by a significant decrease in subsequent events (Table 2).

\section{Broiler litter effects}

It is important to emphasize that the broiler litter applied had been mixed with alum at a $20 \%(\mathrm{w} / \mathrm{w})$ rate. As the companion study showed, alum applications are particularly effective in reducing DP losses in runoff that would otherwise occur from similar amounts of BL applications containing no alum (Martínez et al., 2010). In this case, the effects were expected to be more dramatic since litter was applied before grass establishment and not on top of an established grass as in the other study.

Applications of broiler litter caused significant increases in the dissolved constituents (i.e., DP and $\mathrm{NO}_{3}-\mathrm{N}$ ) concentrations in runoff but not in those moieties (i.e., TP and TKN) for which sediment losses represent a significant transport mechanism (Table 1). Broiler litter appli- 


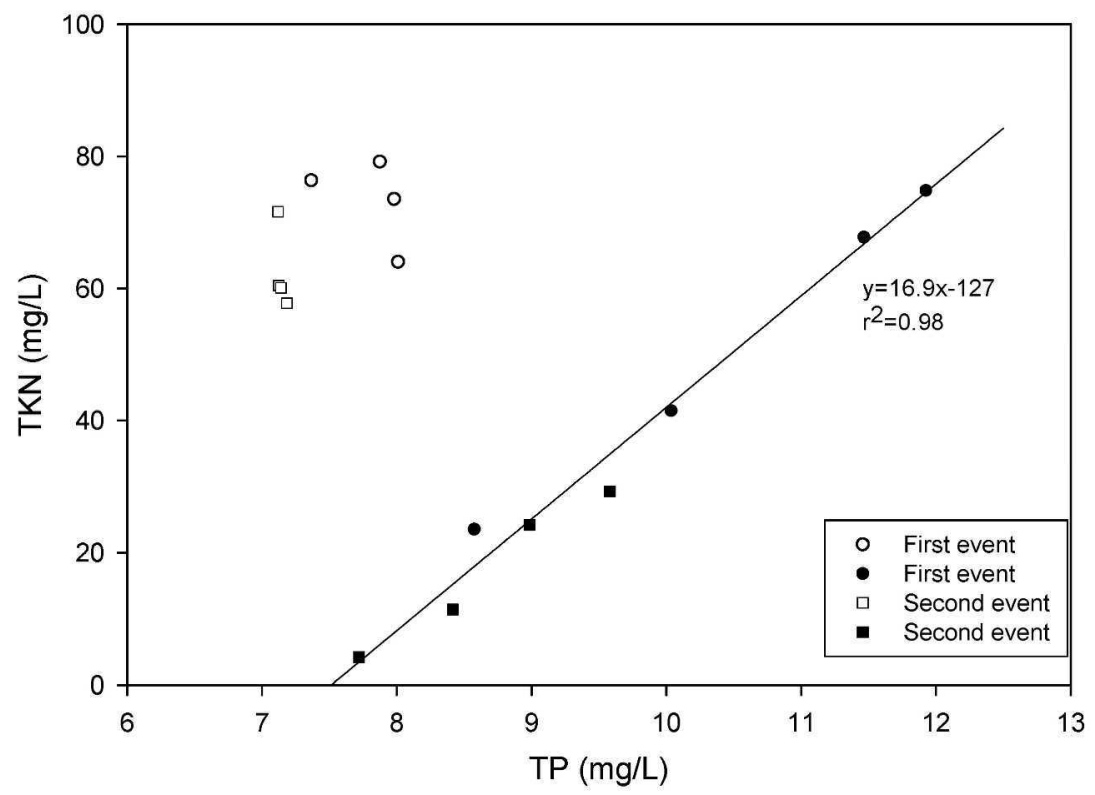

FIGURE 5. Relationship between TP and TKN concentrations in runoff for the bare soils. Open symbols represent unamended experimental units, and filled symbols represent broiler litter-amended units.

cations caused a significant reduction in SS concentration losses at each grass cover category (although much higher losses were observed from bare soils) (Table 3). This result emphasizes the role of the organic amendment in promoting soil aggregate stability. The relationship between SS concentration and broiler litter could be indirectly described by an inverse power expression between Olsen soil test P levels and SS concentrations (Figure 7).

As previously stated, both TKN and TP losses were highly correlated to suspended sediment losses in runoff. Since BL applications reduced SS losses, nutrient additions through BL applications did not necessarily result in higher TP and TKN concentration losses in runoff. For instance, total P losses were not significantly affected by broiler litter applications. This finding is somewhat surprising since litter applications were expected to increase total $P$ concentration losses. The observed behavior may be explained by the counteractive effect of litter applications on SS losses. Whereas litter additions enrich the P nature of the matrix particles, the significant reduction in SS concentrations caused by litter applications reduces the total amount of particle $\mathrm{P}$ 
TABLE 2. Combined effects of ground coverage percentage and runoff event date on the composition of runoff.

\begin{tabular}{lccccccc}
\hline GC $(\%)$ & $\begin{array}{c}\text { Runoff } \\
\text { event }^{1}\end{array}$ & $\begin{array}{c}\mathrm{TP} \\
(\mathrm{mg} / \mathrm{L})\end{array}$ & $\begin{array}{c}\mathrm{DP} \\
(\mathrm{mg} / \mathrm{L})\end{array}$ & $\begin{array}{c}\mathrm{DP} / \mathrm{TP} \\
\%\end{array}$ & $\begin{array}{c}\mathrm{NO}_{3}-\mathrm{N} \\
(\mathrm{mg} / \mathrm{L})\end{array}$ & $\begin{array}{c}\mathrm{TKN} \\
(\mathrm{mg} / \mathrm{L})\end{array}$ & $\begin{array}{c}\mathrm{SS} \\
(\mathrm{g} / 100 \mathrm{ml})\end{array}$ \\
\hline 0 & 1 & $8.98 \mathrm{a}^{2}$ & $0.036 \mathrm{ab}$ & $0.40 \mathrm{~d}$ & $1.45 \mathrm{c}$ & $58.18 \mathrm{a}$ & $1.27 \mathrm{a}$ \\
0 & 2 & $7.84 \mathrm{a}$ & $0.022 \mathrm{~d}$ & $0.29 \mathrm{~d}$ & $1.51 \mathrm{bc}$ & $25.68 \mathrm{~b}$ & $0.88 \mathrm{ab}$ \\
0 & 3 & $6.91 \mathrm{a}$ & $0.041 \mathrm{ab}$ & $0.60 \mathrm{c}$ & $2.42 \mathrm{bc}$ & $11.54 \mathrm{c}$ & $0.65 \mathrm{~b}$ \\
$\geq 80$ & 1 & $0.84 \mathrm{~b}$ & $0.032 \mathrm{bc}$ & $3.78 \mathrm{~b}$ & $7.75 \mathrm{a}$ & $3.60 \mathrm{~d}$ & $0.02 \mathrm{c}$ \\
$\geq 80$ & 2 & $0.50 \mathrm{c}$ & $0.025 \mathrm{~cd}$ & $5.00 \mathrm{~b}$ & $2.98 \mathrm{~b}$ & $2.76 \mathrm{e}$ & $0.01 \mathrm{~d}$ \\
$\geq 80$ & 3 & $0.32 \mathrm{~d}$ & $0.049 \mathrm{a}$ & $15.15 \mathrm{a}$ & $1.36 \mathrm{c}$ & $2.00 \mathrm{f}$ & $0.005 \mathrm{e}$ \\
\hline
\end{tabular}

${ }^{1}$ Runoff event number refers to number of simulations conducted at: 1) initial event (six months after manure application; 2) event conducted seven days after initial event; 3 ) event conducted 21 days after initial event.

${ }^{2}$ Within a column, means followed by the same letter are not different at the $\alpha=0.05$ level of probability according to a LSD test.

movement from the soil. This reduction in turn balances the total $\mathrm{P}$ losses observed relative to the untreated trays. The TKN losses were higher in the control (no broiler litter) than in the $20 \mathrm{t} / \mathrm{ha} \mathrm{BL}$ treat-

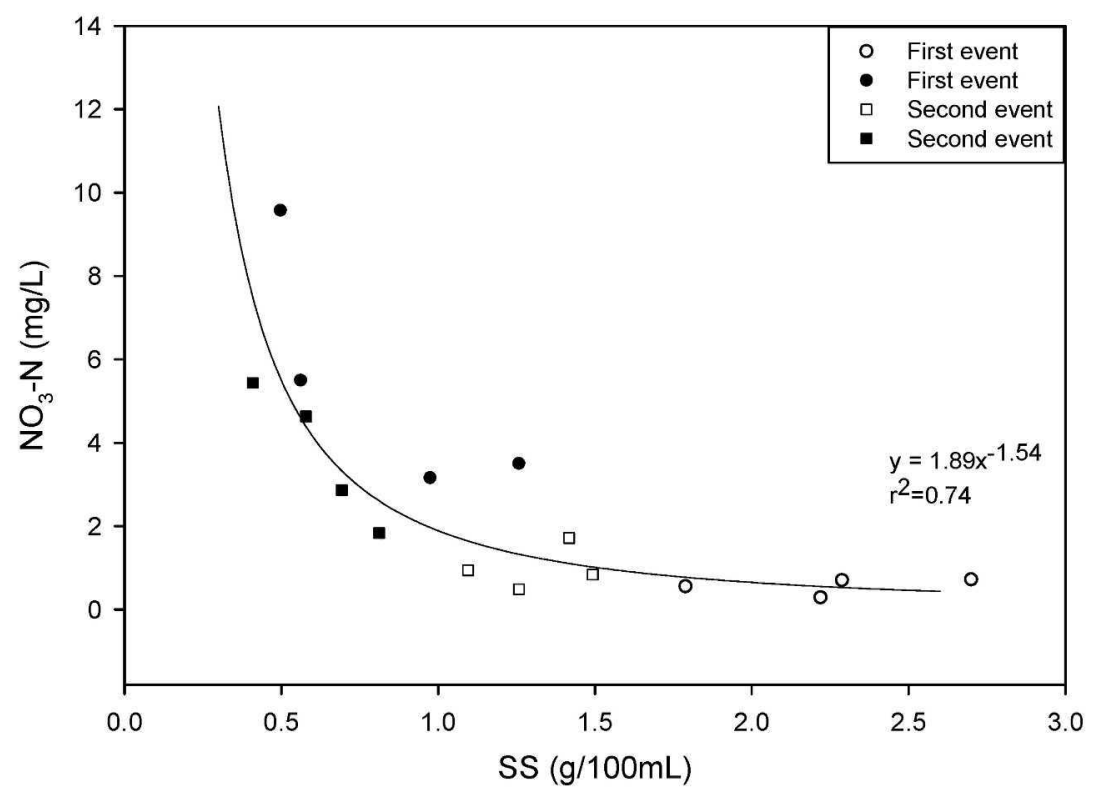

FIGURE 6. Relationship between suspended sediment and $\mathrm{NO}_{3}-\mathrm{N}$ concentrations in runoff for the bare $(0 \%$ cover) soils. Open symbols represent unamended experimental units, and filled symbols represent broiler litter-amended units. 
TABLE 3. Combined effects of ground coverage percentage and broiler litter application rate on runoff composition.

\begin{tabular}{lccccccccc}
\hline $\begin{array}{c}\mathrm{GC} \\
(\%)\end{array}$ & $\begin{array}{c}\text { Litter } \\
\text { rate } \\
(\mathrm{t} / \mathrm{ha})\end{array}$ & $\begin{array}{c}\mathrm{TP} \\
(\mathrm{mg} / \mathrm{L})\end{array}$ & $\begin{array}{c}\mathrm{DP} \\
(\mathrm{mg} / \mathrm{L})\end{array}$ & $\begin{array}{c}\mathrm{DP} / \mathrm{TP} \\
\%\end{array}$ & $\begin{array}{c}\mathrm{NO}_{3}-\mathrm{N} \\
(\mathrm{mg} / \mathrm{L})\end{array}$ & $\begin{array}{c}\mathrm{TKN} \\
(\mathrm{m} / \mathrm{L})\end{array}$ & $\begin{array}{c}\mathrm{SS} \\
(\mathrm{g} / 100 \mathrm{ml})\end{array}$ & $\begin{array}{c}\text { Time } \\
(\mathrm{min})\end{array}$ & $\begin{array}{c}\text { Vol. } \\
\text { runoff } \\
(\mathrm{ml})\end{array}$ \\
\hline 0 & 0 & $7.13 \mathrm{a}^{1}$ & $0.01 \mathrm{~b}$ & $0.11 \mathrm{c}$ & $0.86 \mathrm{~b}$ & $40.78 \mathrm{a}$ & $1.32 \mathrm{a}$ & $3.10 \mathrm{~b}$ & $4,564 \mathrm{a}$ \\
0 & 20 & $8.68 \mathrm{a}$ & $0.14 \mathrm{a}$ & $1.60 \mathrm{~b}$ & $3.53 \mathrm{a}$ & $16.37 \mathrm{~b}$ & $0.62 \mathrm{~b}$ & $3.30 \mathrm{~b}$ & $3,984 \mathrm{a}$ \\
$\geq 80$ & 0 & $0.45 \mathrm{~b}$ & $0.01 \mathrm{~b}$ & $1.60 \mathrm{~b}$ & $1.97 \mathrm{~b}$ & $2.67 \mathrm{c}$ & $0.02 \mathrm{c}$ & $8.56 \mathrm{a}$ & $2,363 \mathrm{~b}$ \\
$\geq 80$ & 20 & $0.59 \mathrm{~b}$ & $0.16 \mathrm{a}$ & $27.39 \mathrm{a}$ & $5.06 \mathrm{a}$ & $2.74 \mathrm{c}$ & $0.005 \mathrm{~d}$ & $7.75 \mathrm{a}$ & $2,767 \mathrm{~b}$ \\
\hline
\end{tabular}

${ }^{1}$ Within a column, means followed by the same letter are not different at the $\alpha=0.05$ level of probability according to a LSD test.

ment. In this case, however, there was a significant interaction between main treatments ( $\mathrm{GC} * \mathrm{BL}$ rate). Under bare conditions, a significant reduction in TKN concentration losses was observed with additions of $\mathrm{BL}$, whereas at greater grass coverage there was no significant effect from BL applications (Table 3 ). The DP losses at the $\geq 80$ grass cover class exhibited a natural logarithmic-type relation with Olsen P values (Figure 8). The

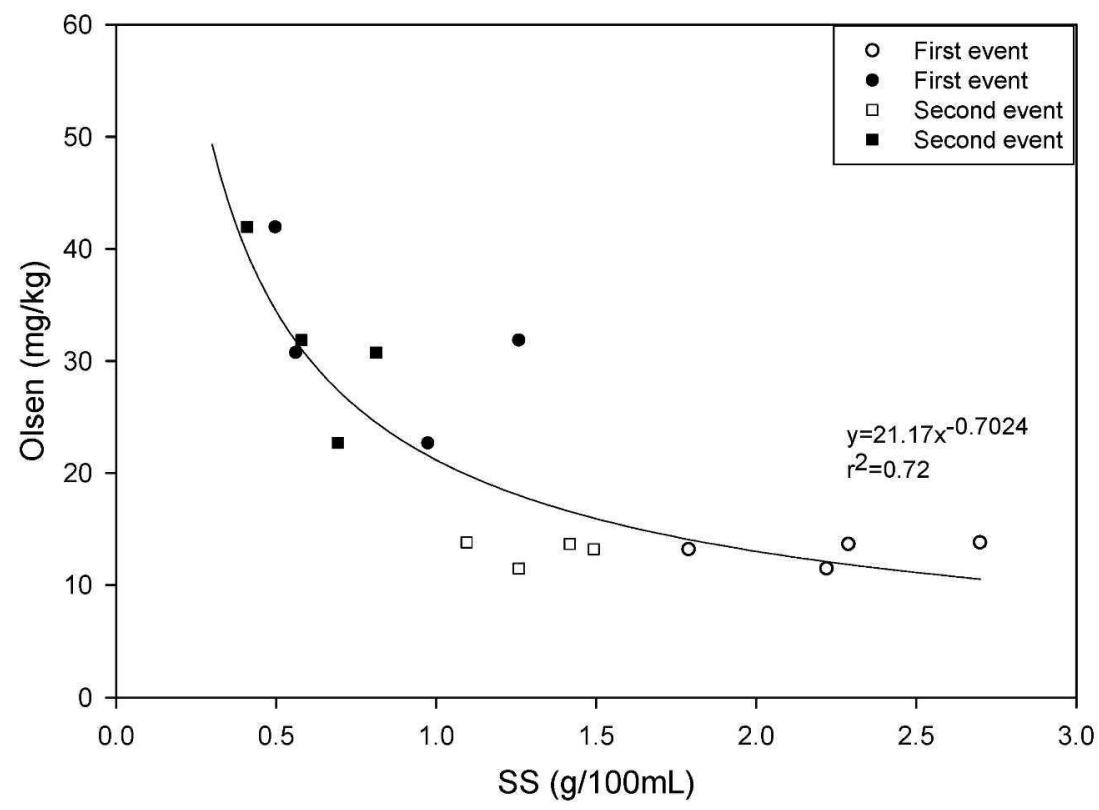

FIGURE 7. Relationship between suspended sediment concentrations in runoff and soil test $\mathrm{P}$ (Olsen) levels for the bare (0\% cover) soils. Open symbols represent unamended experimental units, and filled symbols represent broiler litter-amended units. 


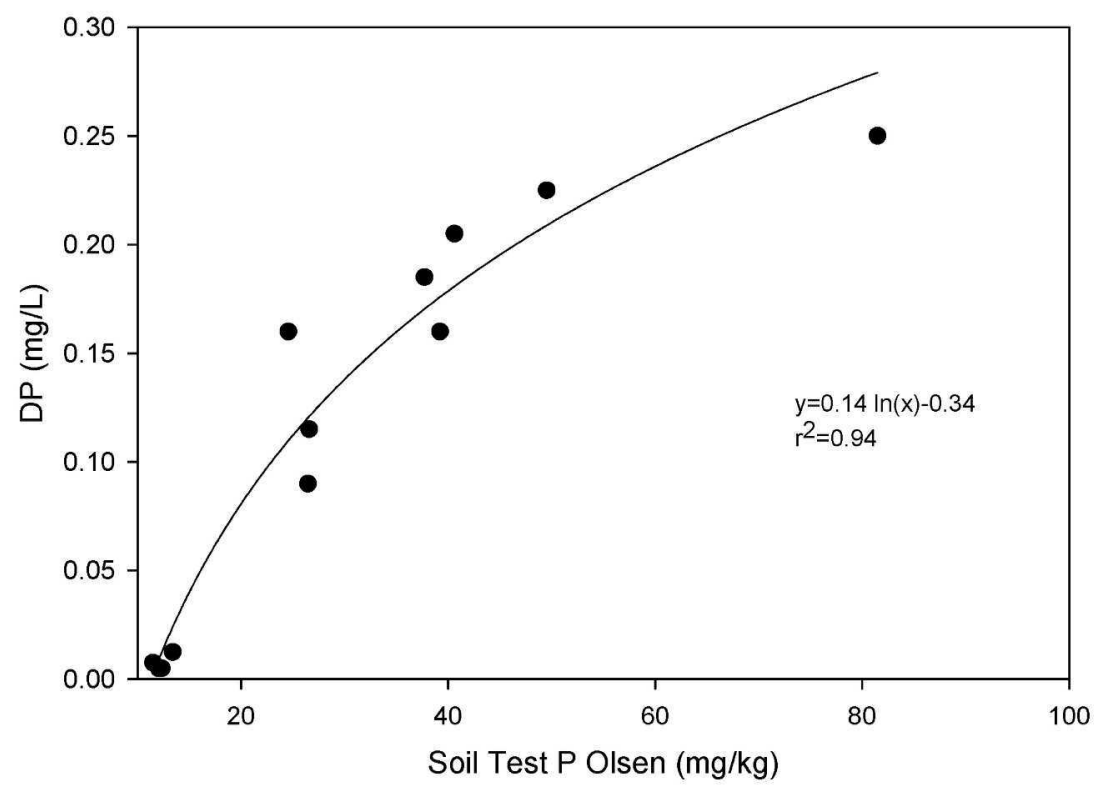

FIGURE 8. Relationship between dissolved $P$ concentrations in runoff and soil test $P$ (Olsen) levels for the grass-covered ( $\geq 80 \%$ ) soils (first rainfall event).

resulting expression $\left(\mathrm{y}=0.14 \operatorname{Ln}(\mathrm{x})-0.34 ; \mathrm{r}^{2}=0.94\right)$ predicts values well below the $1 \mathrm{mg} / \mathrm{L}$ limit for all practical scenarios. As with grass cover, a trend towards a reduction in concentration losses with time was observed for most parameters in treatments containing broiler litter (Table 4).

The magnitude of the impact of grass cover on runoff losses can be better appreciated by considering load losses, a parameter that integrates both concentration and runoff volume losses. Estimates of nutrient and sediment load losses are shown in Table 5. These estimates are presented for illustrative purposes only since our experimental design, based on the use of indoor boxes, is not sensitive to several mechanisms and scale factors that are relevant on the landscape scale. Having stated that difference, we reiterate that the magnitude of the impact of maintaining a good cover stand on reducing contaminant losses from open fields cannot be overlooked. The combination of alum application and a good ( $>80 \%$ ) grass cover reduced estimates of sediment, $\mathrm{TP}$, and TKN runoff export loads by more than $95 \%$ relative to that from the bare soil. 
TABLE 4. Combined effects of broiler litter application rate and runoff event date on runoff composition.

\begin{tabular}{lcccccrc}
\hline $\begin{array}{l}\text { Litter } \\
\text { rate }(\mathrm{t} / \mathrm{ha})\end{array}$ & $\begin{array}{c}\text { Runoff } \\
\text { event }^{2}\end{array}$ & $\begin{array}{c}\mathrm{TP} \\
(\mathrm{mg} / \mathrm{L})\end{array}$ & $\begin{array}{c}\mathrm{DP} \\
(\mathrm{mg} / \mathrm{L})\end{array}$ & $\begin{array}{c}\mathrm{DP} / \mathrm{TP} \\
\%\end{array}$ & $\begin{array}{r}\mathrm{NO}_{3}-\mathrm{N} \\
(\mathrm{mg} / \mathrm{L})\end{array}$ & $\begin{array}{r}\mathrm{TKN} \\
(\mathrm{mg} / \mathrm{L})\end{array}$ & $\begin{array}{c}\mathrm{SS} \\
(\mathrm{g} / 100 \mathrm{ml})\end{array}$ \\
\hline 0 & 1 & $2.51 \mathrm{ab}^{1}$ & $0.007 \mathrm{~d}$ & $0.27 \mathrm{~d}$ & $1.83 \mathrm{c}$ & $17.03 \mathrm{a}$ & $0.340 \mathrm{a}$ \\
0 & 2 & $1.76 \mathrm{c}$ & $0.005 \mathrm{~d}$ & $0.29 \mathrm{~d}$ & $1.16 \mathrm{~d}$ & $12.92 \mathrm{a}$ & $0.160 \mathrm{~b}$ \\
0 & 3 & $1.28 \mathrm{~d}$ & $0.011 \mathrm{c}$ & $0.88 \mathrm{c}$ & $1.05 \mathrm{~d}$ & $5.17 \mathrm{~b}$ & $0.100 \mathrm{bc}$ \\
20 & 1 & $3.00 \mathrm{a}$ & $0.17 \mathrm{a}$ & $5.72 \mathrm{~b}$ & $6.12 \mathrm{a}$ & $12.29 \mathrm{a}$ & $0.088 \mathrm{bc}$ \\
20 & 2 & $2.23 \mathrm{bc}$ & $0.11 \mathrm{~b}$ & $4.94 \mathrm{~b}$ & $3.90 \mathrm{~b}$ & $5.50 \mathrm{~b}$ & $0.059 \mathrm{c}$ \\
20 & 3 & $1.74 \mathrm{~cd}$ & $0.18 \mathrm{a}$ & $10.28 \mathrm{a}$ & $3.16 \mathrm{bc}$ & $4.46 \mathrm{~b}$ & $0.034 \mathrm{~d}$ \\
\hline
\end{tabular}

${ }^{1}$ Within a column, means followed by the same letter are not different at the $\alpha=0.05$ level of probability according to a LSD test.

${ }^{2}$ Runoff event number refers to number of simulations conducted at: 1 ) initial event (six months after manure application; 2) event conducted seven days after initial event; 3 ) event conducted 21 days after initial event.

TABLE 5. Combined effects of ground coverage percentage and broiler litter application rate on runoff export loads.

\begin{tabular}{lcccccc}
\hline $\begin{array}{l}\text { GC } \\
(\%)\end{array}$ & $\begin{array}{c}\text { Litter rate } \\
(\mathrm{t} / \mathrm{ha})\end{array}$ & $\begin{array}{c}\mathrm{SS} \\
(\mathrm{t} / \mathrm{ha})\end{array}$ & $\begin{array}{c}\mathrm{TP} \\
(\mathrm{t} / \mathrm{ha})\end{array}$ & $\begin{array}{c}\mathrm{DP} \\
(\mathrm{t} / \mathrm{ha})\end{array}$ & $\begin{array}{c}\mathrm{TKN} \\
(\mathrm{t} / \mathrm{ha})\end{array}$ & $\begin{array}{c}\mathrm{NO}_{3}-\mathrm{N} \\
(\mathrm{t} / \mathrm{ha})\end{array}$ \\
\hline 0 & 0 & $305.76 \mathrm{a}^{1}$ & $1.62 \mathrm{a}$ & $0.002 \mathrm{c}$ & $9.77 \mathrm{a}$ & $0.21 \mathrm{~b}$ \\
0 & 20 & $121.49 \mathrm{~b}$ & $1.70 \mathrm{a}$ & $0.028 \mathrm{a}$ & $3.48 \mathrm{a}$ & $0.77 \mathrm{a}$ \\
$\geq 80$ & 0 & $2.62 \mathrm{c}$ & $0.05 \mathrm{~b}$ & $0.001 \mathrm{c}$ & $0.27 \mathrm{~b}$ & $0.23 \mathrm{~b}$ \\
$\geq 80$ & 20 & $0.61 \mathrm{~d}$ & $0.07 \mathrm{~b}$ & $0.019 \mathrm{~b}$ & $0.33 \mathrm{~b}$ & $0.61 \mathrm{a}$ \\
\hline
\end{tabular}

${ }^{1}$ Within a column, means followed by the same letter are not different at the $\alpha=0.05$ level of probability according to a LSD test.

Our original experimental design included an additional cover category (50 to $70 \%$ ). However, we were unable to achieve enough replicates of this category for most treatment combinations; therefore, we excluded those results from the analyses. Yet there was one treatment combination ( $1^{\text {st }}$ runoff event, no litter added) for which we had enough replicates to obtain a measure of variability for the different parameters. Figure 9 shows that in most cases there was a strong correlation (negative for $\mathrm{SS}, \mathrm{TKN}$, and TP, but positive for $\mathrm{NO}_{3}-\mathrm{N}$ ) between the percentage of grass coverage and the concentration of the different constituents in runoff.

\section{CONCLUSIONS}

Results from this study demonstrate that maintaining an abundant grass cover is highly effective in efforts to minimize sediment and nutrient runoff losses from broiler litter-amended soils. Average TP and 

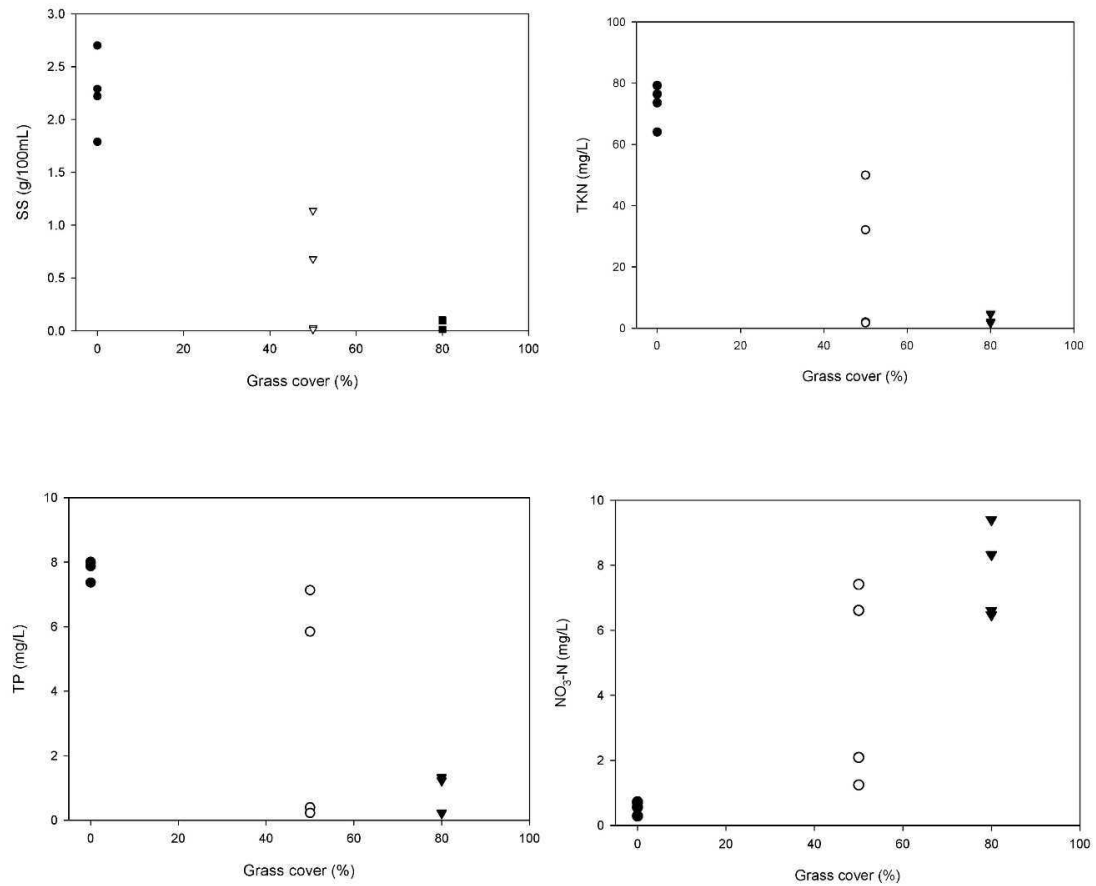

FIGURE 9. Effect of different grass cover categories on runoff composition. Grass cover categories are represented by the following numbers: 0 refers to bare soils; 50 refers to 50 to $70 \%$ coverage; 80 refers to $\geq 80 \%$ coverage.

TKN concentrations in runoff from experimental trays having $\geq 80 \%$ grass cover were $93 \%$ and $89.5 \%$ less, respectively, compared to those of bare soils. Results from suspended solid losses were even more dramatic, with a reduction of $98.9 \%$ over losses from the bare soils. Alum as a litter additive to stabilize $P$ also proved to be an effective best management practice. Even though applications of broiler litter at a $20 \mathrm{t} / \mathrm{ha}$ rate caused significant increases in DP concentrations in runoff, levels remained well below the $1 \mathrm{mg} / \mathrm{L}$ limit suggested to control $\mathrm{P}$ contamination from agricultural lands. Overall, the combination of alum application and $\mathrm{a}>80 \%$ grass cover reduced estimates of sediment, TP, and TKN runoff export loads by more than $95 \%$ relative to the estimates from bare soil, thus proving that in most cases there are technological alternatives for achieving environmental sustainability in these systems. These results would be particularly relevant for recipient farms, which by using an alum-amended litter, could increase substantially 
their litter application loads without compromising the ecological integrity of surrounding waters. However, for this practice to be successful, it must be ensured that litter is applied in the dry season, and that sufficient time is left for pasture establishment before the first significant rainfall events.

\section{LITERATURE CITED}

Lim, T. T., D. R. Edwuards, S. R. Workman, B. T. Larson and L. Dunn, 1998. Vegetated filter strip removal of cattle manure constituents in runoff. Trans. ASAE 41:13751381.

Line, D. E., W. A. Harman, G. D. Jennings, E. J. Thompson and D. L. Osmond, 2000. Nonpoint-source pollutant load reductions associated with livestock exclusion. J. Environ. Qual. 29:1882-1890.

Magette, W. L., R. B. Brinsfield, R. E. Palmer and J. D. Wood, 1998. Nutrient and sediment removal by vegetated filter strips. Trans. ASAE 32:663-667.

Martínez, G. A., R. Macchiavelli and M. A. Vázquez, 2010. Evaluation of best management practices to reduce nutrient contaminant losses in runoff from broiler litter amended soils. I. Alum additions. J.Agric. Univ. P.R. 94(1-2):41-59.

Martínez, G. A., D. Sotomayor and J. A. Castro, 2002. Application of the Caribbean P Index to Tropical Soils Receiving Organic Amendments. J. Agric. Univ. P.R. 86(34):145-154.

Polyakov, V., A. Fares and M. H. Ryder, 2005. Precision riparian buffers for the control of nonpoint source pollutant loading into surface water: A review. Environ. Rev. 13:129-144.

Puerto Rico Environmental Quality Board (PREQB), 2008. Puerto Rico Water Quality Inventory and List of Impaired Waters. 2008. 305(b)/303(d).

Sheridan, J. M., R. Lowrance and D. D. Bosch, 1999. Management effects of runoff and sediment transport in riparian forest buffers. Trans. ASAE 42:55-64.

Smith, R. M. and F. Abruña, 1955. Soil and water conservation research in Puerto Rico, 1938-1947. University of Puerto Rico. Agricultural Experiment Station, Río Piedras, Puerto Rico. Bulletin 124.

Sotomayor-Ramírez, D., G. A. Martínez, O. Santana, R. Mylavarapu and J. L. Guzmán, 2004. Phosphorus soil test for environmental assessment in tropical soils. Comm. Soil Sci. and Plant Anal. 35. (11 \& 12):1485-1503.

USDA, 2001. Confined Animal Production and Litter Nutrients. Agriculture Information Bulletin Number 771.

USDA-NRCS, 2001. National phosphorus project for simulated rainfall: Surface runoff studies. Protocol. Online.http://pswmru.arsup.psu.edu/phosphorus/nprp.htm

USEPA, 1999. National Water Quality Inventory: 1998 Report to Congress. EPA 841-R99-005. Office of Water, USEPA, Washington, DC. 
